\title{
TRADE TENSIONS BETWEEN EU AND RUSSIA: POSSIBLE EFFECTS ON TRADE IN AGRICULTURAL COMMODITIES FOR VISEGRAD COUNTRIES
}

\author{
Vasily Erokhin ${ }^{* 1}$, Wim Heijman², Anna Ivolga ${ }^{3}$ \\ ${ }^{1}$ Moscow University of Finance and Law, Moscow, Russian Federation \\ ${ }^{2}$ Wageningen University, Wageningen, the Netherlands \\ ${ }^{3}$ Stavropol State Agrarian University, Stavropol, Russian Federation
}

\begin{abstract}
The paper includes overview of the current state of the EU-CIS and the EU-Russia trade flows with particular attention to trade in agricultural commodities, as well as contemporary tendencies in agricultural production and foreign trade in agricultural commodities and food in Russia. The paper specifically addresses the possible effects of the trade restrictions between the EU and Russia, particularly the imposed ban on agricultural trade, on the Visegrad countries. The paper is concluded with an overview of the expected influences of the trade tensions on Russia's domestic agricultural market, including consumers, producers, and retailers.
\end{abstract}

Keywords: trade restrictions, ban, agricultural commodities, Visegrad countries

\section{Introduction}

In the conditions of globalization, the effectiveness of agricultural production and sustainability of rural development are increasingly influenced by foreign economic and trade relations. Current uncertain political and economic relations between Russia and the neighbouring countries (the tensions with Ukraine, perspectives of economic and trade relations with the EU, the economic and trade sanctions against Russia, etc.) transform market patterns and affect agricultural production, rural development and food security in the macro-region of Russia, CIS, and the Visegrad region.

Countries of the Visegrad region, which are Slovakia, Poland, the Czech Republic, and Hungary, are traditionally trading partners of Russia in the sphere of agricultural trade. In 2013, the Visegrad countries exported over 1.4 bln Euro worth of agricultural commodities and food to Russia, which was about $4.2 \%$ of the total agricultural export of the four countries. Poland and Hungary are big exporters of meat, fruit and vegetables to Russia. The share of Russia's market in the Visegrad's external trade has been growing over the past decades, as Russia's domestic market has been becoming more dependent on agricultural imports.

According to the FAO, the share of imported agricultural commodities and food on Russia's domestic market exceeds $40 \%$. However, in spite of such a high dependency, Russia has decided to ban most imports of Western food products in retaliation for Western trade and economic sanctions. Such measures will definitely hit the EU-Russia trade relations, including the Visegrad-Russia agricultural trade flow. Not only big food producers, processing plants and retailers, but also a number of small and medium agricultural producers and rural households in the Visegrad countries are expected to experience losses. Such unilateral actions in the conditions of globalized markets completely distort trade patterns and destroy trade links between countries and regions. Trade liberalization definitely opens up new growth opportunities, but also brings threats to sustainable development of national agriculture and food security. Trade restrictions threat sustainable development not only because of their direct effects (market volatilities, destruction of trade linkages, etc.), but to a greater extent because of their hidden effects (distortion of natural economic order, establishment of artificial market environment, overprotection, etc.).

\section{Material and methods}

In order to review the current state of the EU-Russia trade in agricultural commodities, and estimate effects of trade wars, the paper is divided into three parts. The first part includes an outlook of the EU-CIS trade in agricultural commodities. Data on twelve CIS countries and combined EU27 statistics are investigated. The EU-CIS trade in 2012 is analyzed based on AMA/NAMA product classification. The AMA includes agricultural products, while the NAMA refers to all products not covered by the WTO Agreement on Agriculture. In practice, it includes manufactured products, fuels and mining products, and forestry products. They are sometimes referred to as industrial products or manufactured goods. The second part includes an analysis of foreign trade in agricultural commodities and food in Russia. The analysis is conducted for export and import, the analysed period is 2003-2013. Export and import of selected agricultural commodities, as well as top trading partners of Russia, are considered. The expected effects of trade restrictions for the Russia-Visegrad trade in agricultural commodities are evaluated in the third part of the paper. The analysis includes four Visegrad countries, namely Slovakia, Poland, the Czech Republic, and Hungary. The research approach is following: calculation of agricultural exports from the Visegrad countries to Russia in 2013, banned in 2014, and comparison with the total agricultural exports of the Visegrad countries to Russia and to the world in 2013. The analysed period is 1995-2013, the estimations were made for 2014 based on calculated volumes of banned agricultural exports from the Visegrad countries.

Besides trade statistics itself, Russian and foreign researchers and experts have been addressed in the spheres related to the recent developments in the Russia-EU relations and Russia's accession into the World Trade Organization (Tarr and Volchkova, 2010; Ushachev, 2012); influences of trade integration on interregional trade and regional development (Estevadeordal, Freund, Ornelas, 2008; Anderson, Jha, Nelgen, 2013; Josling, Anderson, Schmitz, Tangerman, 2010); sustainable rural and agricultural development in the conditions of fluctuant international environment (Erokhin, Ivolga, Andrei, 2014; Zykova, Ikonnikova, Kononov, 2011; Ivolga, 2014; Ivolga and Erokhin, 2011; Garnik and Sokolnikova, 2014; Savkin and Pervykh, 2013); contemporary 
tendencies of agri-food trade between Visegrad countries and the EU (Bielik, Smutka and Horska, 2012; Bozsik, 2014).

Dialectic, abstract, logical and comparative methods are implemented, as well as factor and correlation analysis of the official statistic data, and study of scientific publications. The data are obtained from the UNCTAD and the Trading Economics databases, as well as from the European Commission reports.

\section{EU-CIS trade in agricultural commodities: outlook}

The EU enlargements in 2004 and 2007 moved the EU external borders to the East and Southeast, changing radically the EU's economic and trade perception of the CIS region and its potential importance as a tradinge partner (particularly for the new EU member states). Russia, Ukraine, Belarus, and Moldova became the direct EU neighbours. In the perspective of Turkey's accession, three other countries (Armenia, Azerbaijan, and Georgia) will also border with the EU. These changes have caused growing integration of the CIS countries towards the world markets. However, two major factors have shaped the pattern of trade openness. The first one is the recovery from the initial transitional slump, not completed until now. There are still incomplete reforms in a number of CIS economies. The second one is the significantly lower level of openness (ratio of foreign trade (export plus import) to GDP) and different barriers to trade in the CIS compared to the rest of the economies in transition (Figure 1).

High growth rates, both for import and export are observed, except 2009. Total trade increased almost threefold and reached $357 \mathrm{bln}$ Euro. Such high level can be explained primarily by growing import from Russia, Kazakhstan, Azerbaijan, and Ukraine.

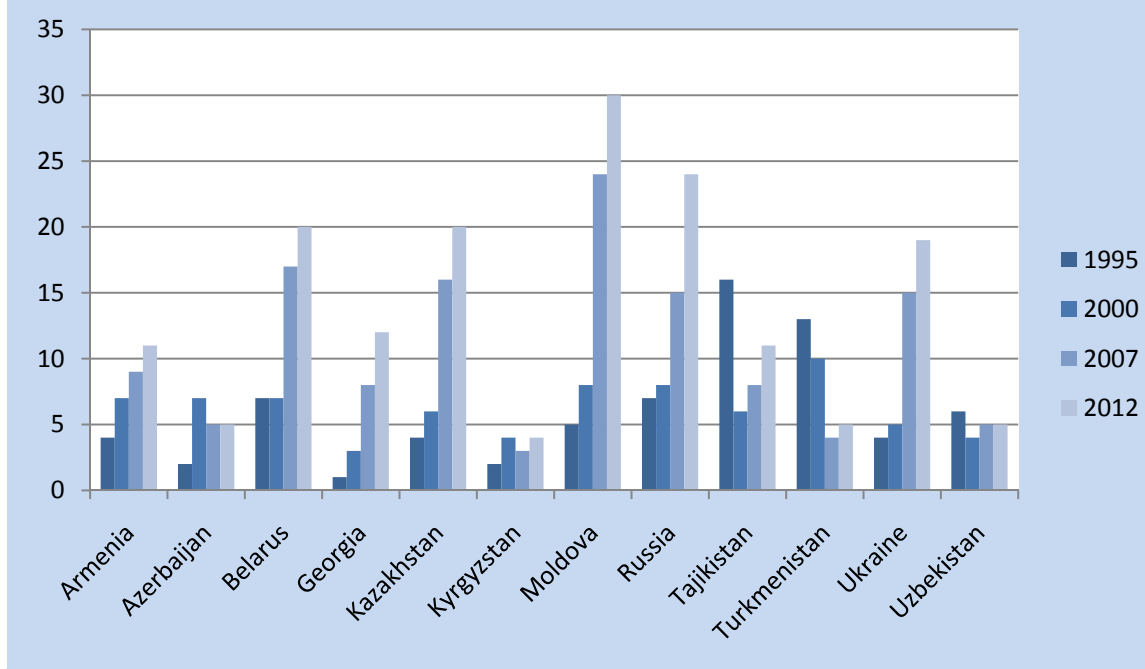

Figure 1 Ratio of foreign trade (export plus import) to GDP in the CIS in its trade with the EU in percentage Source: author's' own processing based on (Koparanova and Li, 2011) and Trading Economics data

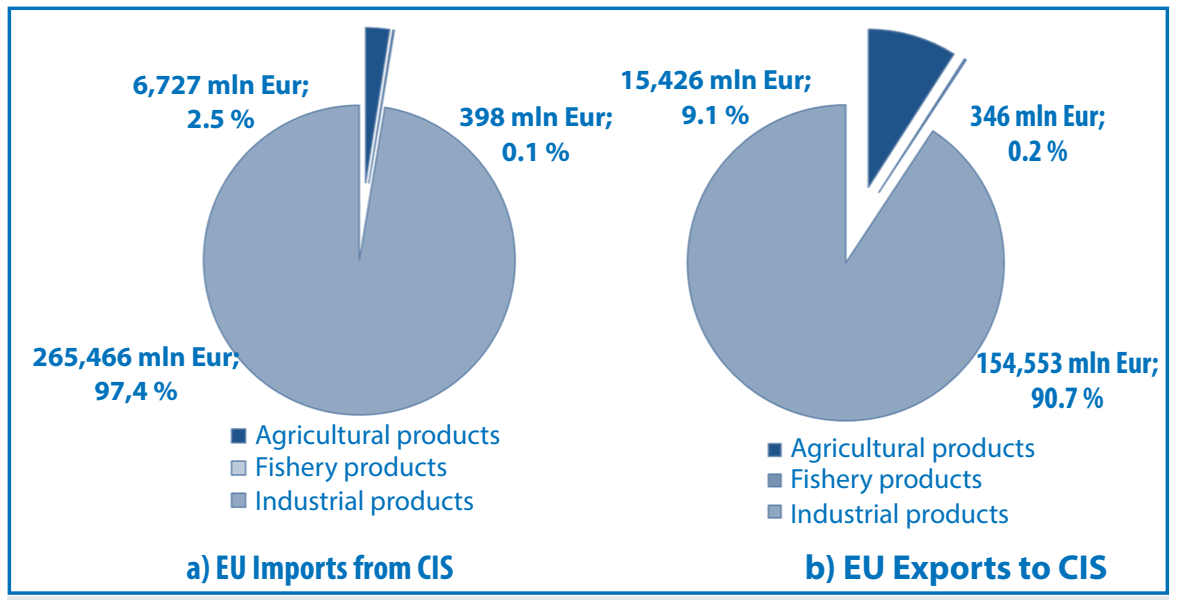

Figure 2 EU-CIS trade in 2012, structure (AMA/NAMA product groups) Source: author's' development based on (European Commission, 2013)

Estimating separate product groups, we may see the domination of industrial products both in exports and in imports (AMA/NAMA product group is considered). The AMA includes agricultural products, while the NAMA refers to all products not covered by the WTO Agreement on

Table 1 EU-CIS trade flows and balance

\begin{tabular}{|c|c|c|c|c|c|c|c|c|}
\hline \multirow[t]{2}{*}{ Period } & \multicolumn{3}{|c|}{ Imports by EU from CIS } & \multicolumn{3}{|c|}{ Exports by EU to CIS } & \multirow{2}{*}{$\begin{array}{c}\text { Balance } \\
\text { in mln Euro }\end{array}$} & \multirow{2}{*}{$\begin{array}{l}\text { Total trade } \\
\text { in } \mathrm{mln} \text {. Euro }\end{array}$} \\
\hline & Value in mln Euro & Growth in \% & Share in Extra-EU in \% & Value in mln Euro & Growth in \% & Share in Extra-EU in \% & & \\
\hline 2002 & 80,192 & & 8.6 & 48,765 & & 5.5 & $-31,427$ & 128,957 \\
\hline 2003 & 84,736 & 5.7 & 9.2 & 52,291 & 7.2 & 6.1 & $-32,445$ & 137,027 \\
\hline 2004 & 101,339 & 19.6 & 10.3 & 63,245 & 20.9 & 6.9 & $-38,094$ & 164,584 \\
\hline 2005 & 131,013 & 29.3 & 11.9 & 75,881 & 20.0 & 7.7 & $-55,132$ & 206,894 \\
\hline 2006 & 162,908 & 24.3 & 13.1 & 96,291 & 26.9 & 9.0 & $-66,617$ & 259,199 \\
\hline 2007 & 165,150 & 1.4 & 12.9 & 113,408 & 17.8 & 10.3 & $-51,742$ & 278,558 \\
\hline 2008 & 201,146 & 21.8 & 14.7 & 129,962 & 14.6 & 11.3 & $-71,184$ & 331,108 \\
\hline 2009 & 128,474 & -36.1 & 12.3 & 82,641 & -36.4 & 8.7 & $-45,833$ & 211,115 \\
\hline 2010 & 171,569 & 33.5 & 13.2 & 103,592 & 25.4 & 9.0 & $-67,977$ & 275,161 \\
\hline 2011 & 213,317 & 24.3 & 15.0 & 124,569 & 20.3 & 9.7 & $-88,748$ & 337,886 \\
\hline 2012 & 219,978 & 3.1 & 15.2 & 137,450 & 10.3 & 10.1 & $-82,528$ & 357,428 \\
\hline
\end{tabular}

Note: Presented financial figures are real (price level 2002), inflation is considered. Inflation figures are obtained from StatBureau.org.

Source: European Commission, 2013 
Agriculture. Naturally, share of the NAMA products is over $90 \%$ in exports, and even close to $98 \%$ of the EU imports from the CIS (Figure 2). That is the global tendency. Over the past years, the NAMA products have accounted for almost $90 \%$ of the world merchandise exports.

Russia is the major trading partner in the region. Import from Russia to the EU has been growing significantly, including the period of global economic recession of 2008-2009.

\section{Foreign trade in agricultural commodities and food in Russia}

Today, with the escalating political conflict between Russia and Ukraine, the economic sanctions imposed by the EU and the USA, and Russia's reorientation on its Asian partners, it is not clear how further progresses can be achieved between Russia and the EU. Nevertheless, the EU is still the major trading partner of Russia, with the share of over $40 \%$ on Russia's external trade turnover. The trade between Russia and the EU grew steadily and reached record levels in 2012. However, there is a slowdown in 2012 followed by the negative trend in 2013. The trend continues in 2014. For the four months to April, the exports to Russia were down by $13 \%$ from the period in 2013 , while imports from Russia declined by $9 \%$. That drop does not seem to be entirely due to the tensions between the EU and Russia over Crimea and eastern Ukraine. It began in 2012, well before those tensions and introduced sanctions. The decline in exports from the EU to Russia (see Table 2) is largely caused by a sharp slowdown of Russia's economy in 2013, while the decline in imports to the EU from Russia reflects a mild start to the year across the Euro area, which has reduced the demand for natural gas.

In 2012, the volume of Russia's GDP in agriculture exceeded $85.5 \mathrm{bln}$ Euro. Russia remains a net-importer of agricultural commodities. Moreover, its dependency on imports has increased. Russia's Import Quota was $41 \%$ in 2012, which means that $41 \%$ of Russia's agricultural GDP is produced by imports, with average EU and USA levels at around 20\%. The largest Russia's import items in 2002-2012 were meat, milk, dairy products, beverages, and sugar. The import deliveries of meat and cheese increased threefold and fourfold respectively during 2002-2012 (Table 3).

However, in spite of such a high dependency, Russia still decided to ban most of Western food products in retaliation for the Western trade and economic sanctions. Russia banned beef, pork, poultry, fish, fruit, vegetables, cheese, milk and other dairy products from the USA, Canada, the EU, Norway, and Australia for one year. Russia imported about 33 bln Euro worth of food products in 2013, of which the banned goods accounted for nearly 7 bln Euro, or $21.2 \%$. The top ten suppliers to Russia include the countries of the Latin

Table 2 EU-Russia trade flows and balance

\begin{tabular}{|c|c|c|c|c|c|c|c|c|}
\hline \multirow[t]{2}{*}{ Period } & \multicolumn{3}{|c|}{ EU imports from Russia } & \multicolumn{3}{|c|}{ EU exports to Russia } & \multirow{2}{*}{$\begin{array}{l}\text { Balance } \\
\text { in } \mathrm{mln} \text { Euro }\end{array}$} & \multirow{2}{*}{$\begin{array}{l}\text { Total trade } \\
\text { in } \mathrm{mln} \text {. Euro }\end{array}$} \\
\hline & Value in mln Euro & Growth in \% & Share in Extra-EU in \% & Value in mln Euro & Growth in $\%$ & Share in Extra-EU in \% & & \\
\hline 2003 & 71,283 & & 7.6 & 37,270 & & 4.3 & & 108,553 \\
\hline 2004 & 82,917 & 16.3 & 8.3 & 45,034 & 20.8 & 4.9 & $-37,883$ & 127,951 \\
\hline 2005 & 108,809 & 31.2 & 9.6 & 54,118 & 20.2 & 5.4 & $-54,691$ & 162,927 \\
\hline 2006 & 133,615 & 22.8 & 10.5 & 67,795 & 25.6 & 6.3 & $-65,820$ & 201,410 \\
\hline 2007 & 130,668 & -2.2 & 10.2 & 80,950 & 19.4 & 7.2 & $-49,718$ & 211,618 \\
\hline 2008 & 161,193 & 23.4 & 11.4 & 93,770 & 15.8 & 8.0 & $-67,423$ & 254,963 \\
\hline 2009 & 105,829 & -34.4 & 9.7 & 58,147 & -38.0 & 6.0 & $-47,682$ & 163,976 \\
\hline 2010 & 140,280 & 32.6 & 10.6 & 74,702 & 28.5 & 6.4 & $-65,578$ & 214,982 \\
\hline 2011 & 169,462 & 20.8 & 11.6 & 91,400 & 22.4 & 7.0 & $-78,062$ & 260,862 \\
\hline 2012 & 177,068 & 4.5 & 12.0 & 101,574 & 11.1 & 7.3 & $-75,494$ & 278,642 \\
\hline 2013 & 168,512 & -4.8 & 12.3 & 97,751 & -3.8 & 6.9 & $-70,761$ & 266,263 \\
\hline
\end{tabular}

Note: Presented financial numbers are real (price level 2003), inflation is considered. Inflation figures are obtained from StatBureau.org.

Source: European Commission, 2014

Table 3 Imports of selected agricultural commodities by Russia in 2002-2012 in bln Euro

\begin{tabular}{|c|c|c|c|c|c|c|c|c|c|c|c|c|}
\hline Item & 2002 & 2003 & 2004 & 2005 & 2006 & 2007 & 2008 & 2009 & 2010 & 2011 & 2012 & 2012 to 2002 in \% \\
\hline Beef & 0.40 & 0.37 & 0.29 & 0.45 & 0.64 & 0.63 & 1.23 & 0.99 & 1.04 & 1.10 & 1.11 & 277.5 \\
\hline Beverage & 0.23 & 0.28 & 0.36 & 0.57 & 0.49 & 0.68 & 0.81 & 0.49 & 0.66 & 0.71 & 0.69 & 300.0 \\
\hline Pig meat & 0.65 & 0.51 & 0.45 & 0.64 & 0.97 & 0.99 & 1.38 & 1.15 & 1.21 & 1.26 & 1.24 & 190.8 \\
\hline Milk & 0.01 & 0.02 & 0.04 & 0.04 & 0.02 & 0.03 & 0.04 & 0.03 & 0.15 & 0.21 & 0.22 & 2200.0 \\
\hline Sugar and honey & 0.05 & 0.05 & 0.06 & 0.05 & 0.05 & 0.05 & 0.04 & 0.05 & 0.08 & 0.08 & 0.09 & 180.0 \\
\hline Poultry & 0.77 & 0.54 & 0.47 & 0.66 & 0.63 & 0.63 & 0.83 & 0.65 & 0.53 & 0.67 & 0.66 & 85.7 \\
\hline Cheese & 0.22 & 0.28 & 0.30 & 0.47 & 0.38 & 0.47 & 0.62 & 0.50 & 0.80 & 0.83 & 0.82 & 372.7 \\
\hline
\end{tabular}

Note: Presented financial numbers are real (price level 2002), inflation is considered. Inflation figures are obtained from StatBureau.org. All financial numbers are calculated in Euro based on average Euro-Ruble ratios for each year

Source: author's' development based on Trading Economics data (http://www.trademap.org) 
Table 4 Top ten suppliers of agricultural commodities to Russia in 2002-2012

\begin{tabular}{|c|c|c|c|c|c|c|c|c|c|}
\hline \multirow[t]{2}{*}{ No. } & \multirow[t]{2}{*}{ Country } & \multicolumn{2}{|c|}{2002} & \multicolumn{2}{|c|}{2005} & \multicolumn{2}{|c|}{2008} & \multicolumn{2}{|c|}{2012} \\
\hline & & volume in mln Euro & share in $\%$ & volume in mln Euro & share in $\%$ & volume in mln Euro & share in $\%$ & volume in mln Euro & share in $\%$ \\
\hline 1 & Turkey & 67.8 & 0.7 & 379.0 & 2.8 & 599.4 & 2.7 & 742.3 & 4.0 \\
\hline 2 & Netherlands & 90.5 & 0.9 & 191.4 & 1.4 & 547.9 & 2.5 & 674.9 & 3.7 \\
\hline 3 & Brazil & 5.4 & 0.1 & 135.8 & 1.0 & 380.9 & 1.7 & 530.8 & 2.9 \\
\hline 5 & Norway & 0.9 & 0.1 & 122.0 & 0.9 & 232.7 & 1.1 & 380.2 & 2.1 \\
\hline 6 & Argentina & 13.4 & 0.1 & 178.3 & 1.3 & 260.4 & 1.2 & 356.4 & 1.9 \\
\hline 7 & China & 45.7 & 0.5 & 221.7 & 1.6 & 446.7 & 2.0 & 315.4 & 1.7 \\
\hline 8 & France & 24.4 & 0.2 & 129.6 & 0.9 & 249.3 & 1.1 & 288.3 & 1.6 \\
\hline 9 & USA & 96.7 & 1.0 & 91.4 & 0.7 & 142.4 & 0.6 & 276.6 & 1.5 \\
\hline
\end{tabular}

Note: Presented financial numbers are real (price level 2002), inflation is considered. Inflation figures are obtained from StatBureau.org. All financial numbers are calculated in Euro based on average Euro-Ruble ratios for each year

Source: author's' development based on Trading Economics data (http://www.trademap.org)

Table 5 Volumes of Visegrad agricultural exports to Russia in 2013, banned in 2014

\begin{tabular}{|c|c|c|c|c|c|c|c|c|c|c|}
\hline \multirow[t]{2}{*}{ Commodity group } & \multicolumn{2}{|c|}{ Slovakia } & \multicolumn{2}{|c|}{ Poland } & \multicolumn{2}{|c|}{ Czech Republic } & \multicolumn{2}{|c|}{ Hungary } & \multicolumn{2}{|c|}{ Visegrad total } \\
\hline & mln Euro & $\% *$ & mln Euro & $\% *$ & $m \ln$ Euro & $\% *$ & mln Euro & $\% *$ & $\mathrm{mln}$ Euro & $\% *$ \\
\hline Meat and meat preparations & 4.16 & 18.18 & 115.58 & 10.52 & 1.39 & $1, .66$ & 61.82 & 28.23 & 182.95 & 12.85 \\
\hline Fish, crustaceans, molluscs and preparations there of & 0.00 & - & 2.08 & 0.19 & 0.10 & 0.12 & 0.00 & - & 2.18 & 0.15 \\
\hline Fruit and vegetables & 0.05 & 0.22 & 564.23 & 51.38 & 3.96 & 4.74 & 41.82 & 19.09 & 610.06 & 42.85 \\
\hline Total & 8.15 & 35.62 & 803.16 & 73.14 & 21.82 & 26.09 & 111.48 & 50.90 & 944.61 & 66.35 \\
\hline
\end{tabular}

Note: Presented financial numbers are real (price level 2013). All financial numbers are calculated in Euro based on average Euro-USD ratios for each year, obtained from www.bloomberg.com

* Percentage in total agricultural export to Russia

Source: author's' development based on UNCTAD statistics ((http://unctadstat.unctad.org/)

America, Europe, and Asia (Table 4). Five out of the top-ten are banned, which are the Netherlands, Poland, Norway, France, and the USA.

The ban is expected to hit about $7 \%$ of the EU agricultural exports to Russia. However, for certain EU countries, i.e. Poland, France, and Norway, losses may be more essential. Russia used to be a large market for Polish fruits, French cheese and Norwegian fish. The United States do not expect any serious losses, since Russian market is less than $1 \%$ of the total US agricultural export. Russia considers Brazil and Turkey as the most likely alternative suppliers. Indeed, beef, pork and poultry products from Brazil could serve as substitutes. New Zealand could help make up for the banned cheese, while Turkey could ship more fruits, vegetables and dairy products.

\section{Expected effects of trade restrictions for the Russia-Visegrad trade in agricultural commodities}

Slovakia, Poland, the Czech Republic, and Hungary were also hit by the trade restrictions. Russia banned three kinds of meat and meat products, fish, fruit and vegetables, and all dairy products. As of the UNCTAD, those commodities are included into four commodity groups (Table 5).

Poland is the worst-hit country among the Visegrad countries, since over $73 \%$ of its agricultural exports to Russia (which is over 803 $\mathrm{mln}$ Euro), are turned out to be banned. The expected losses of Hungary are far lower: $111 \mathrm{mln}$ Euro, or $50 \%$ of the total agricultural exports to Russia. The Czech Republic and Slovakia do not

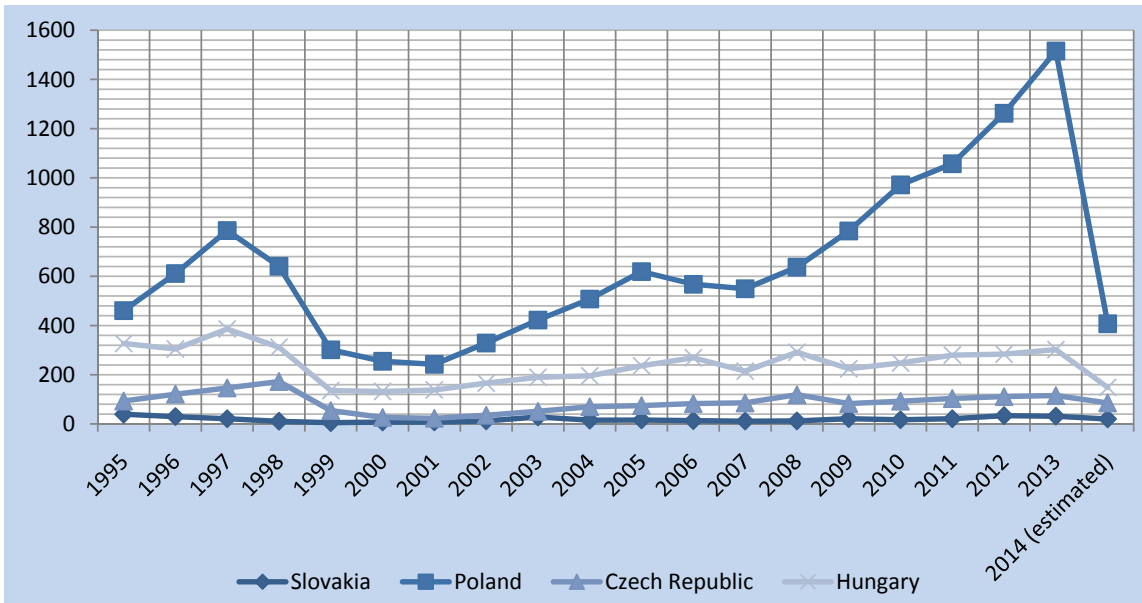

Figure 3 Dynamics of Visegrad agricultural exports to Russia in 1995-2013 and the estimated cutback in exports in 2014 due to the ban in mIn Euro Note: Presented financial numbers are real (price level 1995), inflation is considered Source: author's' development based on UNCTAD statistics ((http://unctadstat.unctad.org/) 
Table 6 Volumes of Visegrad agricultural exports, banned by Russia, and their shares in overall Visegrad agricultural exports to the world in 2013

\begin{tabular}{|c|c|c|c|c|c|c|c|c|c|c|}
\hline \multirow[t]{2}{*}{ Commodity group } & \multicolumn{2}{|c|}{ Slovakia } & \multicolumn{2}{|c|}{ Poland } & \multicolumn{2}{|c|}{ Czech Republic } & \multicolumn{2}{|c|}{ Hungary } & \multicolumn{2}{|c|}{ Visegrad total } \\
\hline & mln Euro & $\%^{*}$ & mln Euro & $\% *$ & mln Euro & $\% *$ & mln Euro & $\% *$ & mln Euro & $\% *$ \\
\hline Meat and meat preparations & 4.16 & 0.14 & 115.58 & 0.63 & 1.39 & 0.02 & 61.82 & 0.87 & 182.95 & 0.54 \\
\hline Fish, crustaceans, molluscs and preparations thereof & 0.00 & - & 2.08 & 0.01 & 0.10 & 0.01 & 0.00 & 0.01 & 2.18 & 0.01 \\
\hline Fruit and vegetables & 0.05 & 0.01 & 564.23 & 3.09 & 3.96 & 0.07 & 41.82 & 0.59 & 610.06 & 1.80 \\
\hline Milk, dairy products and cheese & 3.94 & 0.13 & 121.27 & 0.66 & 16.36 & 0.29 & 7.85 & 0.11 & 149.42 & 0.44 \\
\hline Total & 8.15 & 0.27 & 803.16 & 4.39 & 21.82 & 0.39 & 111.48 & 1.58 & 944.61 & 2.78 \\
\hline
\end{tabular}

Note: Presented financial numbers are real (price level 2013). All financial numbers are calculated in Euro based on average Euro-USD ratios for each year, obtained from www.bloomberg.com * Percentage overall agricultural export of the country

Source: author's' development based on UNCTAD statistics ((http://unctadstat.unctad.org/)

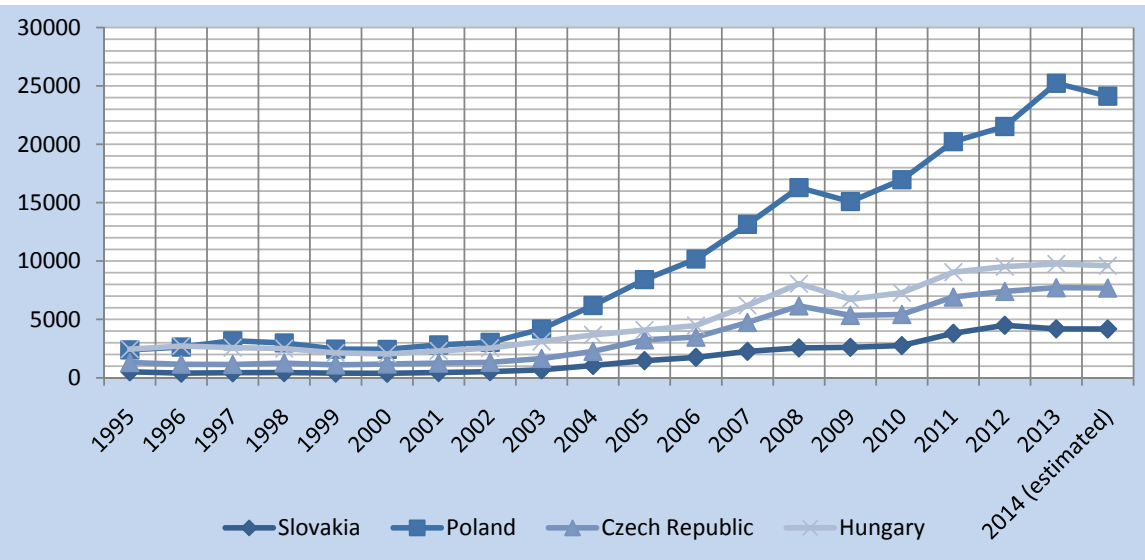

Figure 4 Dynamics of the Visegrad total agricultural exports in 1995-2013 and the estimated cutback in exports in 2014 due to the Russia's trade ban in $\mathrm{mln}$ Euro Note: Presented financial numbers are real (price level 1995), inflation is considered Source: author's' development based on UNCTAD statistics ((http://unctadstat.unctad.org/)

have such strong trade links with Russia in the sphere of agriculture as Poland and Hungary, that is why their damages are expected to be slight about one third of the total agricultural exports to Russia. We may expect the Poland - Russia and the Hungary - Russia agricultural trade flows to be rebound to the levels of the early 2000s, while the Slovakia - Russia and the Czech Republic Russia trade flows are not expected to be affected seriously (see Figure 3).

However, the shares of agricultural exports, banned by Russia, in overall agricultural exports from the Visegrad countries to the world are very small. That is why the losses do not seem to be crucial. The worst-hit Visegrad country is again Poland, which has the biggest agricultural turnover with Russia. Russia's ban is accounted to approximately $4.4 \%$ of overall Poland's agricultural exports (see Table 6).

Russia is an important market for Poland, but not a crucial one. Poland sells six times as much to Germany. The figure is even lower for Hungary $-1.6 \%$, while Slovakia and the Czech Republic may even not notice Russia's restrictions and easily reorient their exports or pass through the ban. The dynamics of the Visegrad-world trade in agricultural commodities shows that only Poland may experience sensible cutback of its agricultural exports in 2014 due to the Russia's trade sanctions (Figure 4). Poland lost a big market for its apples, but vegetables is even the greater cause for concern. Apples can be stored for several months while vegetables (especially peppers and cabbage) have to be sold immediately after harvesting. Since about $40 \%$ of paprika, produced in Poland, used to be exported to Russia, the losses for particular branches may be essential.

The trade war with Russia could shave around half a percentage point of the Polish economic growth in 2014. The government previously expected the growth of $3.3 \%$ this year (Walker and Dalton, 2014). There are two options for Polish farmers: to wait for the EU compensations, or to rapidly reorient their exports. The EU agriculture commissioner Dacian Ciolos promised to speed up compensation procedures regarding the most sensitive Polish agricultural products, namely those which cannot be stored for longer periods of time (Kassam et al., 2014). The European Commission already declared that it was drawing on provisions in the reformed
Common Agricultural Policy (CAP), which includes an emergency reserve of $€ 420 \mathrm{mln}$ Euro in total to compensate EU farmers for market disruption. The money will be available between August and the end of November 2014 (EurActiv, 2014). However, until compensations come, many of the Polish fruit and vegetables will head for the EU market, potentially displacing their more expensive European rivals. Others will go to markets in Asia and the Middle East, traditionally supplied by EU countries such as France. The same situation is expected to happen in the other Visegrad countries: Hungarian, Czech and Slovakian farmers will either seek for alternative markets inside or outside the EU, or claim compensations forom national and EU officials.

\section{Conclusions}

Despite certain expected losses of the Visegrad countries and the other EU member states due to the Russia's agricultural ban, Russia itself may turn out to be damaged in a greater extent. Regardless of the world's biggest territory and high volumes of domestic agricultural production, Russia remains a net-importer of agricultural commodities. Moreover, its dependency on imports has increased. Currently, over $41 \%$ of Russia's agricultural GDP is produced by imports, with average EU and USA levels at around 20\%. Russia received up to $55 \%$ of its agricultural imports from the countries it has so far sanctioned, including the EU. Almost $50 \%$ of Russia's meat imports and about $95 \%$ of Russia's dairy imports in 2013 came from countries it has now banned, with its biggest suppliers until now being the Netherlands, Germany, Lithuania, Finland, and Poland (Jalonic and Baetz, 2014).

Taking into account the high Russia's dependency on foreign agricultural products and food, the imposed agricultural ban is like a double-edged sword for Russia. On the one hand, it is an opportunity for domestic producers to fill a market gap. However, Russian farmers are not 
able to increase their production rapidly, their facilities are outdated, financial resources are limited, and quality of their products is low (Erokhin and Ivolga, 2012). On the other hand, the ban would definitely backfire by driving up domestic food prices, at least in the short term. Unfortunately, the biggest losers in this will be Russian consumers, who will pay more for their food now as well as in the long run. They will definitely not be compensated anyhow, contrary to the EU farmers. The ban will hit consumers, along with a number of Russian industries, including food processing plants, shippers and retailers. Growth of unemployment and bankruptcies of food processing enterprises are expected.

Until recently Russia was not among the WTO members. Russia's accession to this global trading system in 2012 and membership of some CIS countries in the WTO are considered as preconditions for essential structural changes in interregional and even international trade. However, latest trade sanctions imposed on both sides between Russia and the Western countries demonstrated that the WTO had not much to do with those changes. The real threats for the Russia-Visegrad and the Russia-EU trade are unilateral actions, which completely distort trade patterns and destroy trade links between countries and regions.

The WTO experiences of most of the CIS countries in relation to agriculture have not been very positive until now. Trade integration has resulted in growing competition on domestic markets and inflow of foreign food and agricultural products. However, trade restriction is even a bigger evil, since it distorts natural economic order, creates artificial market environment and drives overprotection. Domestic agricultural producers have to be protected and supported, but not through trade bans. One of the tools to protect national economies and ensure sustainable development is integration of agrarian markets into the inter-regional market and establishment of the common agrarian market. There is the Customs Union of Russia, Belarus and Kazakhstan already. This common market should be developed into the alternative to the EU, USA and Asian markets. But it should grow naturally, through higher competitiveness of domestic agricultural producers, bigger exports, integration of the best Western practices and technologies into domestic production, and not through any imposed restrictions.

\section{References}

ANDERSON, K. - JHA, S. - NELGEN, S. 2013. Re-examining policies for food security in Asia. In Food Security, vol. 5, 2013, no. 2, p. 195-215.

BBC NEWS EUROPE. 2014. Russia's trade ties with Europe. Accessed at http://www.bbc. com/news/world-europe-26436291 on August, 27, 2014.

BIELIK, P. - SMUTKA, L. - HORSKA, E. 2012. Development of Mutual Agricultural Trade of Visegrad Group Countries. In Visegrad Journal on Bioeconomy and Sustainable Development, vol. 1, 2012, no. 1, p. 2-11.

BOZSIK, N. 2014. The state of agri-food export of the Visegrad countries in EU markets. In Visegrad Journal on Bioeconomy and Sustainable Development, vol. 3, 2014, no. 1, p. 2-8.

EROKHIN, V. - IVOLGA, A. 2012. How to Ensure Sustainable Development of Agribusiness in the Conditions of Trade Integration: Russian Approach. In International Journal of Sustainable Economies Management (IJSEM), vol. 2, 2012, no. 1, p. $12-23$.

EROKHIN, V. - IVOLGA, A. - ANDREI, J. V. et al. 2014. Contemporary Issues of Sustainable Rural Development: International Approaches and Experiences of Eastern Europe and Russia. Stavropol, Russia : AGRUS of Stavropol State Agrarian University, 2014.
ESTEVADEORDAL, A. - FREUND, C. - ORNELAS, E. 2008. Does Regionalism Affect Trade Liberalization Toward Nonmembers? In The Quarterly Journal of Economics, vol. 124, 2008, no. 4, p. 1531-1575.

EURACTIV. 2014. Russia's sanctions threaten both EU farmers and policymakers. Accessed at http://www.euractiv.com/sections/agriculture-food/russias-sanctions-threatenboth-eu-farmers-and-policymakers-307827 on August, 27, 2014.

EUROPEAN COMMISSION. 2013. European Union, trade in goods with CIS. Accessed at http://trade.ec.europa.eu/doclib/docs/2006/september/tradoc_113479.pdf on August, 27, 2014

EUROPEAN COMMISSION. 2014. European Union, trade in goods with Russia. Accessed at http://trade.ec.europa.eu/doclib/docs/2006/september/tradoc_113440.pdf on August, 27, 2014.

GARNIK, S. - SOKOLNIKOVA, 0. 2014. Impact of WTO accession on agriculture sustainable development in the Russian Federation. In Visegrad Journal on Bioeconomy and Sustainable Development, vol. 3, 2014, no. 1, p. 33-38.

GUSEV, A. 2012. Russia's Accession into the WT0: Real Consequences. In Observer, 2012, no. 10, p. 26-39.

IVOLGA, A. 2014. Overview of contemporary issues of sustainable rural development in Russia in terms of existing differences between regions. In Economics of Agriculture, 2014, no. 2, p. 331-345.

IVOLGA, A. - EROKHIN, V. 2011. Rural development and agrarian reform: Russian experience during the transition period. Proceedings, International Conference Rural Development Policies from the EU Enlargement Perspective, Ecka, Republic of Serbia, 2011. p. 137-144.

JALONIC, M. C. - BAETZ, J. 2014. US, EU farmers feel hit from Russia food ban. Daily World, accessed at http://www.dailyworld.com/story/news/2014/08/09/us-eu-farmersfeel-hit-russia-food-ban/13830999/ on August, 27, 2014.

JOSLING, T. - ANDERSON, K. - SCHMITZ, A. - TANGERMAN, S. 2010. Understanding International Trade in Agricultural Products. One hundred years of contributions by agricultural economists. In American Journal of Agricultural Economics, vol. 2, 2010, no. 92, p. 424-446.

KASSAM, A. et al. 2014. Russian food embargo leaves Europe with glut of fruit, pork and mackerel. The Guardian, accessed at http://www.theguardian.com/world/2014/ aug/15/ukraine-europe-news on August, 27, 2014.

SAVKIN, V. - PERVYKH, N. 2013. Food resources as the basis of the sustainable development and national security in the age of economic globalization. In Visegrad Journal on Bioeconomy and Sustainable Development, vol. 2, 2013, no. 1, p. 28-33.

TARR, D. - VOLCHKOVA, N. 2010. Russian Trade and Foreign Direct Investment Policy at the Crossroads. Policy Research Working Paper, Series 5255, The World Bank, 2010.

TRADING ECONOMICS DATA. Accessed athttp://www.trademap.org/ on August, 27, 2014. UNCTAD STATISTICS. Accessed at http://unctadstat.unctad.org/ on August, 27, 2014.

USHACHEV, I. 2012. Measures to Secure Competitiveness of Russia's Agricultural Production in the Conditions of its Accession to WTO. In Economics of Agricultural and Processing Enterprises: Academic and Research Journal, 2012, no. 6, p. 1-5.

WALKER, M. - DALTON, M. 2014. Russian import ban will hit European food producers. The World Street Journal, accessed at http://online.wsj.com/articles/eu-mulls-furtheraction-after-russian-ban-1407414110 on August, 27, 2014.

ZYKOVA, N. - IKONNIKOVA, 0. - KONONOV, 0. 2011. Diversification of Rural Economics: Problems and Perspectives. In Russian Entrepreneurship, vol. 2 (196) 2011, no. 11, p. 151-155.

\section{Contact addresses}

Vasily Erokhin, PhD, Faculty of Master Business Administration,School of the Moscow University of Finance and Law MFUA, 8 build. 1, Presnenskaya Embankment, Moscow, Russian Federation, 5 ? 7-499-995-19-63, e-mail: basilic@list.ru 